\title{
The Identification of Human and Animal Blood Mixtures Using Human Cytochrome b Gene
}

\author{
Wimbuh Tri Widodo ${ }^{\mathbf{1}}$, Abdul Hadi Furqoni ${ }^{2}$, Ahmad Yudianto ${ }^{\mathbf{3}}$, Sri Puji Astuti Wahyuningsih ${ }^{\mathbf{4}}$ \\ ${ }^{1,2}$ Forensic Science, Graduate School, ${ }^{3}$ Forensic Medicine and Medicolegal Department, Faculty of \\ Medical, ${ }^{4}$ Biology Department, Faculty of Science and Technology, Airlangga University, Surabaya \\ Indonesia \\ wimbuh.tri.widodo-2015@pasca.unair.ac.id
}

\begin{abstract}
Human and animal blood has a similar composition so it is difficult to distinguish between the two. The aim of this study was to identify human blood from human and animal blood mixtures using the cytochrome bene that has a species-specific DNA sequence. The DNA extracted from varied human and chicken blood was amplified using a human-specific cytochrome b gene primer. The result showed that $10 \%$ human blood from the mixtures could be identified and the DNA extracted from the human blood could be amplified. The concentration of $0.01 \mathrm{ng}$ still showed the appropriate DNA band. The primer was very sensitive and specific, so it useful for forensic purposes to verify human blood in a blood mixture.
\end{abstract}

Keywords-Polimerase Chain Reaction (PCR), DNA, human and Animal Blood Mixtures, human cytochrome b

\section{INTRODUCTION}

The origins of forensic casework samples must be determined to be human or animal (non-human). Human and animal bloods especially blood has a similar composition (red blood cells, white blood cells and platelets) so it is very difficult to distinguish between the two. The classical methods for identification based on protein analysis [1,2] were are not applicable to the forensic casework.

New methods have emerged based on genetic differences. Cytochrome $b$ markers have shown good feasibility in detecting species of origin from the sample mixtures. The nucleotide sequence of the cytochrome $b$ gene contains species-specific information and has been used in food safety as well as in forensic investigations in a number of studies $[3,4,5,6]$.

Furthermore, the cytochrome $b$ gene is located in the mitochondrial genome. The mitochondrial genome of vertebrates is made up of small, circular double-stranded DNA molecules that present up to several thousand copies per cell [7]. This gene location takes advantage of the sensitivity of PCR-based DNA analysis in the forensic context.

In the present study, the authors applied PCR-based analysis using cytochrome $b$ to identify human blood from human and chicken blood mixtures and reveal how it level in the mixtures can be detected.

\section{MATERIAL AND METHODS}

\section{A. Primer ordering}

This study used a human cytochrome $\mathrm{b}$ gene primer which was designed by Matsuda [8] and ordered from PT. Genetika Science, Indonesia. Forward primer 5'TAGCAATAATCCCC ATCCTCCATATAT-3', reverse primer 5'-ACTTGTCCAAT GATGGTAAAAGG-3'

\section{B. Bloods preparation}

Human peripheral blood samples were obtained from the Indonesian Red Cross (PMI) while the animal blood samples were obtained from a chicken farm.

\section{DNA extraction}

DNA from human blood, chicken blood and human and chicken blood mixtures were extracted using the Wizard Genomic DNA Purification Kit (Promega) according to the respective manufacturer's instructions. The concentrations of the extracted DNA were determined by UV absorbance using a spectrophotometric reading at $260 \mathrm{~nm}$.

\section{Primer specificity test}

The specificity of the primer was confirmed by the amplification of $100 \mathrm{ng}$ DNA from human blood and chicken blood. The amplification was conducted in a 50 ul volume; containing $2 \mathrm{ul}$ template DNA, 2X GoTaq Green Master Mix (reaction buffer $(\mathrm{pH} 8.5), 400 \mu \mathrm{M}$ of all four dNTP and $3 \mathrm{mM}$ $\mathrm{MgCl}$ ), 0,3 uM forward primer, $0.3 \mathrm{uM}$ reverse primer. PCR was performed in a thermal cycler for 30 cycles of $30 \mathrm{~s}$ at $95^{\circ}$ $\mathrm{C}, 40 \mathrm{~s}$ at $55^{\circ} \mathrm{C}$, and $1 \mathrm{~min}$ at $72^{\circ} \mathrm{C}$. The products of the PCR amplification were electrophoretically determined in a $2 \%$ agarose gel containing ethidium bromide in a $0.5 \mathrm{X}$ TBE (Tris-Borate-EDTA) buffer and visualised by UV transillumination. 


\section{E. Minimal DNA template concentration test}

DNA from the human blood was diluted using aqudest (100 ng, $10 \mathrm{ng}, 0.1 \mathrm{ng}, 0.01 \mathrm{ng}$ ). Each dilution was used as a template in PCR amplification according to the primer specificity test. Minimal DNA template concentration was determined by PCR amplification of the DNA extracted from humans at levels of $0.01,0.1,10,100 \mathrm{ng}$ of DNA in water.

\section{F. Minimal percentage of human blood test}

Human blood and chicken blood was mixed and extracted in ratios of $0: 100,50: 50,25: 75,10: 90,5: 95,100: 0$. DNA from this extraction was used as a template in PCR amplification according to the previous analysis.

\section{RESULTS AND DISCUSSION}

\section{A. Specificity of the primers}

The specificity for human DNA was evaluated using DNA extracted from human and chicken blood as template DNA in amplifications with the human cytochrome $b$ gene primer. In the agarose gel electrophoresis, the DNA of animals produced no visible bands whereas human DNA showed a single band of the expected size of approximately 157 bp (Fig.1)

\section{B. Minimal DNA template}

The minimal DNA template was determined by PCR amplification of the DNA extracted from human blood at levels from 0.01 to $100 \mathrm{ng}$ of DNA in water. The DNA templates were still successfully amplified at $0.01 \mathrm{ng}$ (Fig.2).

\section{Minimal percentage of human blood}

The results of the PCR reactions for the DNA extracted from human and animal blood mixtures showed that detection of the human blood was successful in mixtures from $10 \%$ to $50 \%$ level. Mixtures containing 5\% human blood were not successfully amplified (Fig.3).

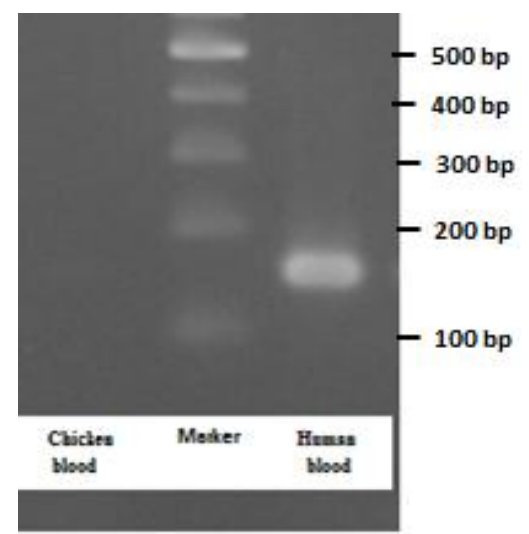

Fig. 1. Agarose gel electrophoresis (2\%) of PCR product amplified from human blood and chicken blood; Marker : 100bp DNA Ladder

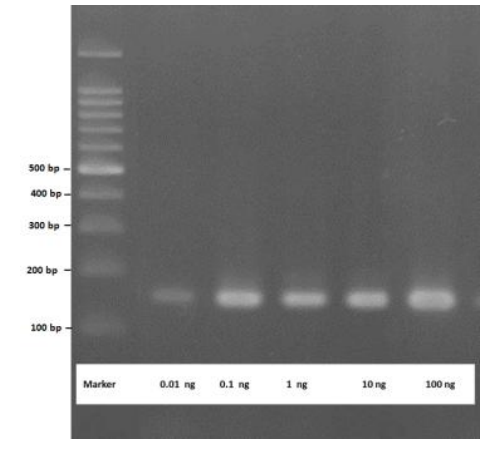

Fig. 2. The result of minimal DNA template concentration test on $2 \%$ agarose gel; $0.01,0.1,10,100 \mathrm{ng}$ : DNA template concentration; Marker : 100bp DNA Ladder

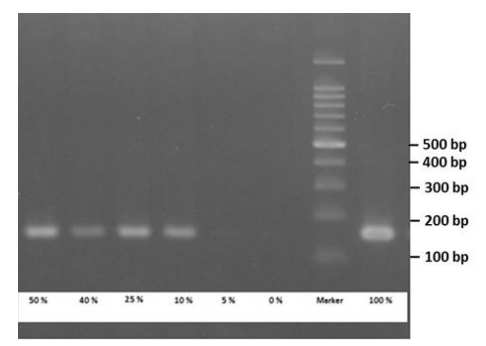

Fig. 3. The result of minimal percentage of human blood on $2 \%$ agarose gel; $50 \%, 40 \%, 25 \%, 10 \%, 5 \%, 0 \%, 10 \%$ : percentage of human blood in mixtures; Marker : 100bp DNA Ladder

\section{Discussion}

In this study, species-specific PCR was applied for the identification of human and animal blood mixtures using a cytochrome $b$ gene that had a species-specific sequence. According to the alignment analysis, the chicken cytochrome $\mathrm{b}$ gene has 13 differences in the regions targeted by the human cytochrome b gene primer. Similarly, monkey, gorilla and other primates who are closely-related with humans also have 10-13 differences in the regions targeted by the human cytochrome $\mathrm{b}$ gene primer. Chicken blood was therefore used as a representative of animal blood. DNA extracted from the human blood was successfully amplified while the DNA extracted from human blood was not. The DNA bands obtained were $157 \mathrm{bp}$ according to Masuda [8]. It was designed to amplify the human cytochrome $b$ gene sequence from the 902 th base to 1058th base. The results also showed that the human cytochrome $b$ gene was specifically targeted so that only the human DNA would be amplified.

The minimal DNA template of the primers depends on it sequences. The primer detected the presence of $0.01 \mathrm{ng}$ of the DNA template from human blood while the other cytochrome $\mathrm{b}$ gene primer showed a positive result of $0.25 \mathrm{ng}$ [8], 0.0001 ng $[9,10], 0.01 \mathrm{ng}[11]$ in the DNA template. The cytochrome $\mathrm{b}$ gene has many copies and is located in the mitochondrial DNA which causes it to be very sensitive and easily detected.

The 10\% level of human blood from the human and chicken blood mixtures could be detected but the 5\% level was not. The identification of the sample mixtures using the cytochrome $\mathrm{b}$ gene could be performed until a $0.1 \%$ level [3, $12]$. 
In mammalian blood including humans, mitochondrial DNA is found in white blood cells which make up only $1 \%$ of whole human blood. Mitochondrial DNA in the 5\% level mixtures did not show up in as many of the other human sample mixtures. It was one of reasons that the $5 \%$ level mixtures showed a negative result.

\section{CONCLUSION}

PCR-based DNA analysis using the human cytochrome $b$ gene primer was very specific, sensitive and simple so it was a suitable method to detect blood in the sample mixtures for forensic purposes.

\section{References}

[1] H. Amini Najafabadi, M. Paknejad, S. Farshad, T. Mohammadian, S. S. Seyyed Ebrahimi, and A. Amini Najafabadi, "Immunodot blot assay to detect Helicobacter pylori using monoclonal antibodies against the $26 \mathrm{kDa}$ protein.," Hybridoma (Larchmt)., vol. 31, no. 6, pp. 403-10, 2012.

[2] H. J. Skarpeid, R. E. Moe, and U. G. Indahl, "Detection of mechanically recovered meat and head meat from cattle in ground beef mixtures by multivariate analysis of isoelectric focusing protein profiles," Meat Sci., vol. 57, no. 3, pp. 227-234, 2001.

[3] H. Shabani, M. Mehdizadeh, S. M. Mousavi, E. A. Dezfouli, T. Solgi, M. Khodaverdi, M. Rabiei, H. Rastegar, and M. Alebouyeh, "Halal authenticity of gelatin using species-specific PCR," Food Chem., vol. 184, pp. 203-206, 2015.

[4] A. Lopez-Oceja, D. Gamarra, S. Jiménez-Moreno, and M. M. de Pancorbo, "Identification of big game species by a universal cytochrome
B primer pair through High-Resolution Melting," Forensic Sci. Int. Genet. Suppl. Ser., vol. 5, pp. e116-e117, 2015.

[5] S. Ferreira, A. R. Oliveira, A. Farinha, M. T. Rebelo, and D. Dias, "Forensic entomology: Nuclear and mitochondrial markers for Diptera and Coleoptera identification," Forensic Sci. Int. Genet. Suppl. Ser., vol. 3, no. 1, 2011.

[6] A. Lopez-Oceja, D. Gamarra, S. Borragan, S. Jiménez-Moreno, and M. M. De Pancorbo, "New cyt b gene universal primer set for forensic analysis,” Forensic Sci. Int. Genet., vol. 23, pp. 159-165, 2016.

[7] X. Chen, R. Prosser, S. Simonetti, J. Sadlock, G. Jagiello, and E. A. Schon, "Rearranged mitochondrial genomes are present in human oocytes," Am. J. Hum. Genet, vol. 57, no. 2, pp. 239-247, 1995.

[8] H. Matsuda, Y. Seo, E. Kakizaki, S. Kozawa, E. Muraoka, and N. Yukawa, "Identification of DNA of human origin based on amplification of human-specific mitochondrial cytochrome b region," Forensic Sci. Int., vol. 152, no. 2-3, pp. 109-114, 2005.

[9] M. H. M. Yusop, S. Mustafa, Y. B. C. Man, A. R. Omar, and N. F. K. Mokhtar, "Detection of Raw Pork Targeting Porcine-Specific Mitochondrial Cytochrome B Gene by Molecular Beacon Probe RealTime Polymerase Chain Reaction," Food Anal. Methods, vol. 5, no. 3, pp. 422-429, 2012.

[10] E. Dilworth and J. Frey, "A rapid method for high throughput DNA extraction from plant material for PCR amplification," Plant Mol. Biol. Report., vol. 18, no. 1, pp. 61-64, 2000.

[11] Z. Kesmen, F. Sahin, and H. Yetim, "PCR assay for the identification of animal species in cooked sausages," Meat Sci., vol. 77, no. 4, pp. 649653, 2007.

[12] J. Nikzad, S. Shahhosseini, M. Tabarzad, N. Nafissi-Varcheh, and M. Torshabi, "Simultaneous detection of bovine and porcine DNA in pharmaceutical gelatin capsules by duplex PCR assay for Halal authentication," DARU J. Pharm. Sci., vol. 25, no. 1, p. 3, 2017. 